\title{
An Overview of International Capital Flows and Its Impact on Chinese Financial Market
}

\author{
Yunxin $\mathrm{Yi}^{1{ }^{1, *}}$ \\ ${ }^{1}$ The University of Melbourne Faculty of Business and Economics Australia, Victoria. Melbourne
}

\begin{abstract}
With the acceleration of economic globalization and financial market integration, there has been a gradual increase in the amount of international capital and considerable global movement of capital flow. Due to its inherent uncertainty, immense capital flows, and complex structure, international capital flows have an enormous impact on international trade, finance flowing, and economic development for countries all over the world. This paper aims to provide a full overview of international capital flow, focusing on the internal fluctuation patterns and developing trends in the near future. Through the qualitative analysis of China's capital flows, this paper also summarizes its major characteristics and multiple effects caused by international capital flows.
\end{abstract}

\section{Introduction}

How does international capital flow? What are the factors driving the capital movement? How it may affect a country's financial market? These topics have drawn extensive attention worldwide, and there is also an increasing volume of literature that recognizes the importance of international capital flows. They are the logical products of global economic integration, because as more economic activities involve the crossing of national borders, globalization of capital flows inevitably begins to emerge and grow. In general, international capital is going through the contradiction of supply and demand. Viewed from the supply side, heavily impacted by a series of financial crises, multiple developed countries are in deep recession, and would prefer to invest in the domestic market rather than invest in foreign countries. Meanwhile, although emerging economies enjoy sound momentum with potential economic growth, there is still a lack of enough capital to invest in the international market. From the perspective of demand, most countries are striving to attract the inflow of international capital to boost the economy and return to pre-recession levels. Needless to say, it is of great significance to understand the features and mechanism of international capital flows as well as their effects on financial stability and economic growth. Therefore, this paper provides a comprehensive summary of international capital flows, including related concepts, classification, and global overview. Furthermore, this paper also sets out to investigate different impacts on advanced and emerging economies by analyzing the internal structure of capital flows. Lastly, this paper conducts a qualitative analysis on the effects of international capital flows on Chinese financial markets.

\section{Overview of International Capital Flows}

Under a multilateral network in the new global economy, the flow of capital has been regarded as a critical issue for international trade, financial stability, and economic opportunities. More broadly, with its inherent nature of making capital active and floating among different entities, it also has become a significant component for promoting technological change and denationalizing international relations. The scale and structure of capital flows can vary considerably over time during different phases of the economic cycle, especially when taking the disparity of national conditions into consideration. Moreover, an increasing number of academic researchers and practitioners have pointed out that different forms of capital flow demonstrate its distinct features, which makes it less predictable and manageable in the global financial system. Therefore, due to their huge volume, along with unstable and procyclical nature, international capital flows are in close association with multiple kinds of financial risks, including exchange rate volatility, spillover effects, and dollar liquidity crunches [1].

The outbreak of COVID-19 has also led to renewed interest in the area of international capital flow. This pandemic crisis has caused major disturbances for global capital flows and the current system of exchange rates. According to a recently released report by Organization for Economic Co-operation and Development (OECD), as early in March, 2020, both emerging and mature economies have stopped cross-border portfolio investment, and it is expected that the foreign direct investment (FDI) flows have dropped by approximately $40 \%$ [2]. Combined with the collapsing oil prices, the outbreak of COVID-19 also resulted in wild swings in the

*junxiny@student.unimelb.edu.au 
foreign exchange market. Starting from the end of February 2020, most emerging economies have experienced a sharp fall in their exchange rates, particularly for those key players including Russian Federation, Brazil, Mexico, and South Africa [2]. By contrast, several developed economies maintained the steady growth of their currencies throughout this period, or recovered sooner from the bottom of the slump. Although the hardest-hit currencies are gradually getting back on track, the sudden stop of international capital flows also flagged the importance of understanding their impact on the global financial market and finding the most effective tools to cope with the upcoming crises.

Therefore, by investigating the mechanism and development trend of global capital flows, we aim to gain a better insight into their direct and indirect effects on the country's central market, monetary policy, financial management order, as well as possible solutions in addressing the financial crisis. The following sections will focus on discussing related concepts and the classification of international capital flows, and will give an overall picture of the flow of capital across countries.

\subsection{Concepts and Classification}

International capital flows refer to the transfer, namely inflow and outflow, of monetary capital among national entities [3]. In the field of finance, capital flows can reflect the financial transactions for the purpose of international trade, international investment, and business productions. From the perspective of capital structures, capital flows can also be regarded as the movement of financial assets in both global and domestic markets, which can include bank deposits, equity securities, venture capital, and mutual funds.

There are various possible external and internal factors in driving capital flows. Typically, capital inflow means the amount of capital resources entering a country due to the growing confidence for its economic prospects. Meanwhile, capital outflow refers to the phenomenon where financial or monetary assets are moving away from a specific nation [4]. Large quantities of capital outflow are widely treated as undesirable results, for it might indicate the economic uncertainty and political instability, or at least some perceptions of it.

Another method of classifying the international capital flows is based on the use term of capital, and they can be divided into long-term and short-term international capital flows. It is noticeable that long-term international capital flows often have a longer duration and occupy a large number of funds, and this type of capital flow plays a major part in sustaining a country's economic stability and in promoting the integration of regional currency. The fundamental cause of the long-term international capital flows is the enhancement of world productivity and the pronounced division of labor. Depending upon the different ways of capital transfer, long-term international capital flows can be further classified as direct investment, securities or portfolio investment, and international loans.

In contrast, the most prominent features for short-term international capital movements include short, flexible duration of use and good liquidity [5]. It has multiple forms including trade capital movement, bank capital flows, hedge capital flows, and speculative capital flows, and quite sensitive to the government economic policies, such as interest rates, exchange rates, and currency control. Speculative capital transference, also known as "hot money", or "refugee capital", is very likely to take place under the floating rate system and may have disruptive effects on the safety of the banking and financial systems. Figure 1 shows an overview of different types of international capital flows.

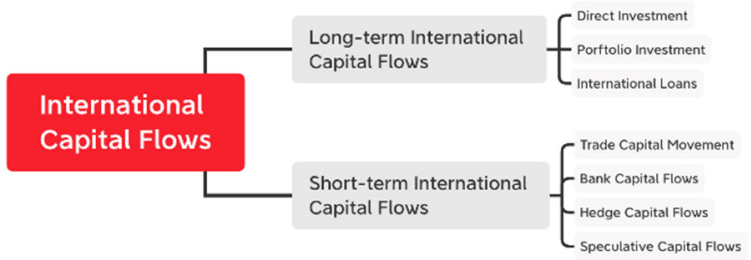

Figure 1. Classification of International Capital Flows

Overall speaking, it is quite obvious that international capital flows have important implications on both financial and economic development nearly in every nation, for its unique role in keeping the equilibrium of the balance of payment (BOP) and in balancing the international payments and receipts [6].

\subsection{Global Overview}

When conducting a global overview of international capital flows, this paper mainly focuses on examining several fundamental features from the following dimensions:

\subsubsection{Total Scale}

The total scale of international capital flows indicates the dollar value of capital flows. Both the World Bank and the International Monetary Fund calculate this metric by summing up all the total imports and total exports from all countries. Following the same method, this paper retrieved worldwide data from the World Economic Outlook Database over the last two decades. To ensure continuity and comparability over time, all the value has been measured in US dollars at current prices in millions. Figure 2 presents an overview of international capital flows from 2001 to 2020.

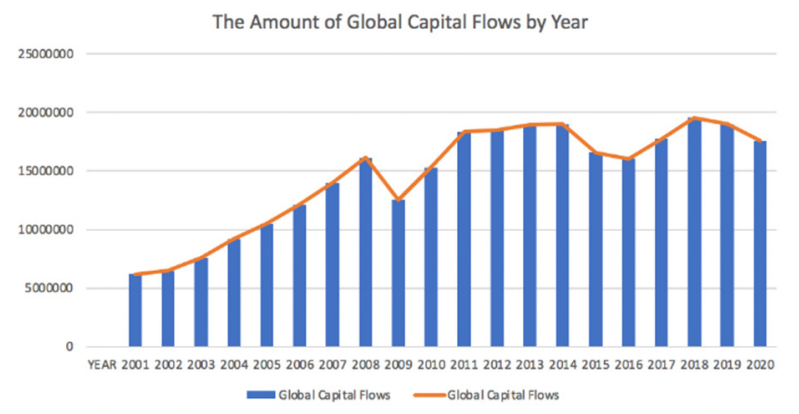

Figure 2. Overview of International Capital Flows from 2001 to 2020 
As can be seen from the figure above, the total scale of international capital flow demonstrates periodic fluctuations in nature. Despite the slight decline in the amount of capital flows in the year of 2009, 2015, and 2016, the overall size of capital flows continued to rise through the years. The first noticeable turning point is the 2008 Financial Crisis. The well-known, high market volatility and financial turbulence led to a lower risk appetite among the public, causing most countries to tighten the enforcement of their regulations on capital flows. Even though nearly no large markets have escaped the 2008 global financial crisis unscathed, there has been a budding economic recovery in the following years, and the pace of international trade for goods and services is improving as well. Another financial shock of international capital flow took place for two consecutive years since 2015. It is widely considered that this ongoing capital contraction in 2016 was closely associated with a series of US-centric policies adopted by the Trump administration. When looking at the latest trends, it is presumed that the recent downturn starting from 2019 resulted from the COVID-19 pandemic crisis. During the most difficult time, a broad sell-off in equity markets began to spread around the globe, and financial conditions had been seizing up to avoid volatile, painful crashes [2]. For example, as mentioned previously, investors started to pull out of the emerging markets and the financial flows between national entities appear to have come to a sudden stop ever since March 2020. These circumstances have in turn dramatically impacted international trade and global capital flows.

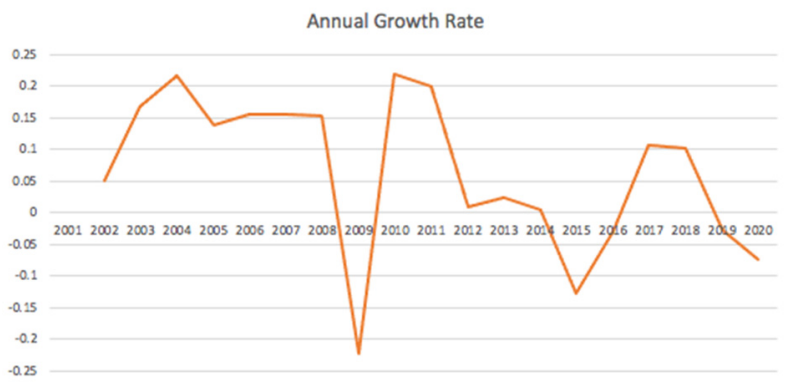

Figure 3. Annual Growth Rate of International Capital Flows

Figure 3 further provides the summary statistics of the rate of changes in international capital flows, and the whole tendency is consistent with our observations and conclusion from Figure 2. The annual growth rate turned down sharply in the time period of 2008-2009, 2015-2016, and 2019-2020.

\subsubsection{Emerging and Advanced Economies}

To better understand the overall trend of international capital flow among different countries, this paper also analyzes the time series data of capital movement in both emerging and advanced economies, including the Euro area, major advanced economies (G7), emerging market and developing economies, as well as emerging and developing Asia. The primary source of this set of capital flow data is also the International Monetary Fund's (IMF) World Economic Outlook Database. To ensure the accurate reporting of global trends and the comparability between data, this paper gathered the total volume of capital flows by country groups, and divided these data by their countries' GDP to calculate the percentage change value. The results are shown in Figure 4.

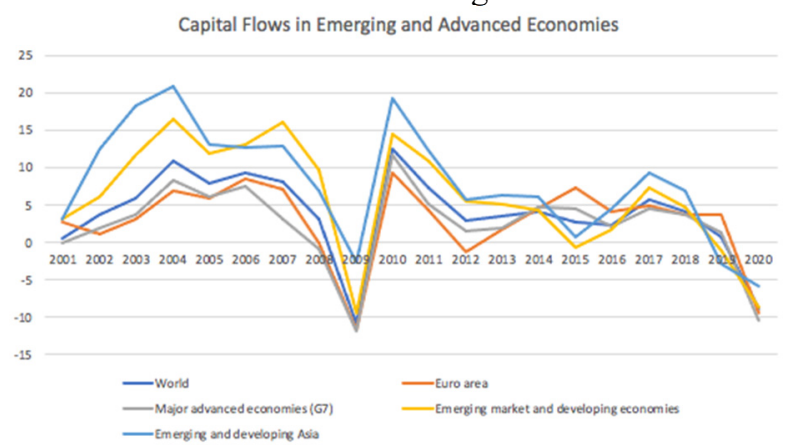

Figure 4. Capital Flows in Emerging and Advanced Economies

Regardless of the development level of countries, the whole tendency of capital flows is remarkably consistent with Figure 3. This paper also finds out that, for emerging markets, the rate of changes in their capital flows is far above those in the world's capital flows. Emerging and developing Asia has the highest annual percentage change, followed by the entire emerging markets and developing economies. By contrast, the rate of changes for advanced economies varied steadily and are generally less than the world's overall level. This phenomenon implies that, compared with mature markets, emerging economies are more sensitive to external financial conditions and outside environment variety. Therefore, for emerging economies including China, it is especially momentous to pay more attention to establishing a financial policy framework and adjusting related regulations to uphold international financial stability.

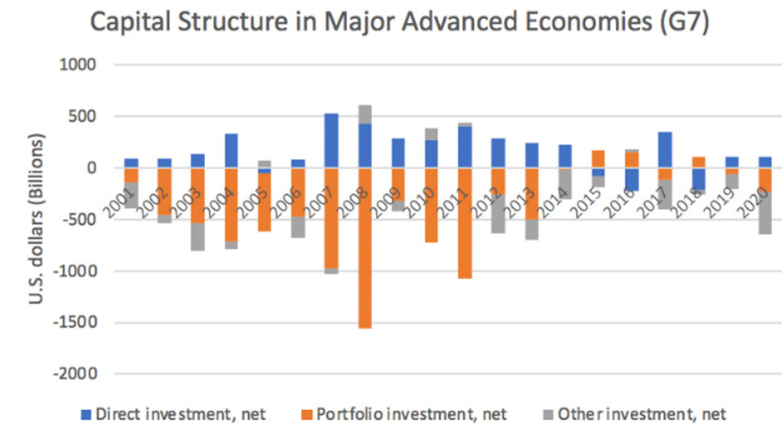

Figure 5. Capital Structure in Major Advanced Economies (G7)

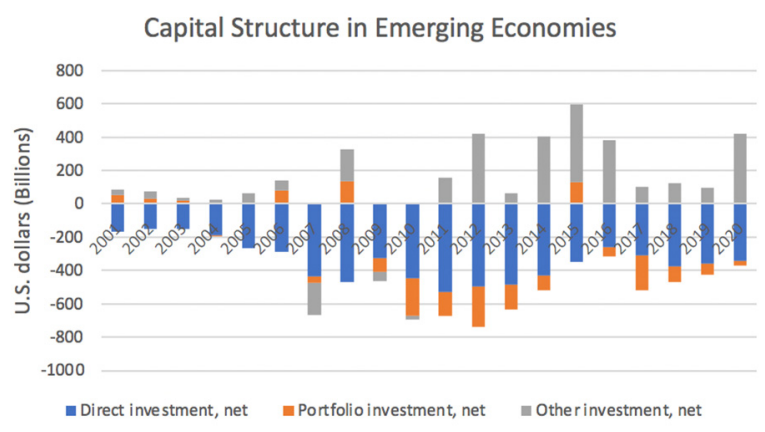

Figure 6. Capital Structure in Emerging Economies 
The internal structure of capital flows in advanced economies and emerging economies is summarized in Figure 5 and Figure 6 respectively. Although they consist of the same three components, namely direct investment, portfolio investment, and other investment, the distribution features can be quite divergent over time in different economies. Portfolio investment accounted for the largest number of capital flows in emerging economies, whereas in advanced economies, direct investment and other investments outweighed the rest. Moreover, these three components have different volatility features in the inflow and outflow of capital movement as shown in Table 1. Portfolio investment and other investment have higher volatility, and they are likely to flow back to their own country during the financial crisis, with negative figures in 2008, 2015, and 2020. These facts also have strong implications for economic development and global policy-making.

Table1. Summary Statistics of Capital Flows

\begin{tabular}{|c|c|c|}
\hline $\begin{array}{c}\text { Country } \\
\text { Group Name }\end{array}$ & Subject Descriptor & $\begin{array}{l}\text { Standard } \\
\text { Deviation }\end{array}$ \\
\hline \multirow{3}{*}{$\begin{array}{c}\text { Major } \\
\text { advanced } \\
\text { economies } \\
(\mathrm{G} 7)\end{array}$} & Direct investment, net & 199.249894 \\
\hline & Portfolio investment, net & 431.475893 \\
\hline & Other investment, net & 158.180079 \\
\hline \multirow{3}{*}{$\begin{array}{l}\text { Emerging } \\
\text { market and } \\
\text { developing } \\
\text { economies }\end{array}$} & Direct investment, net & 115.843905 \\
\hline & Portfolio investment, net & 105.750925 \\
\hline & Other investment, net & 179.217597 \\
\hline
\end{tabular}

\section{Impact on Chinese Financial Markets}

From the previous analysis, it can be concluded that developed countries are the major sources, but also the final destinations of global liquidity [13]. They also have greater say in determining the scale and cycle of crossborder capital flows. However, as emerging economies boom, the impact of international capital flows on them has also been brought into the limelight and provoked heated discussions in the academic and industrial world. And China is a critical research subject to look at among emerging countries. With the sharp development of the economy and the growing strength of the Chinese Yuan, China has been widely recognized as a powerful force in the international arena. As China deepens its reform and opening-up policy, the inflow of foreign capital has been a great engine of domestic economic growth, but also caused the national economy to suffer from the turmoil in financial markets. In this section, this paper would first briefly introduce the general trend of capital flows in China. It will then go on to analyze the combined effects of international capital flows on Chinese financial markets, and several recommendations to hedge away the negative shocks of capital flows.

\subsection{Overview of China Capital Flows}

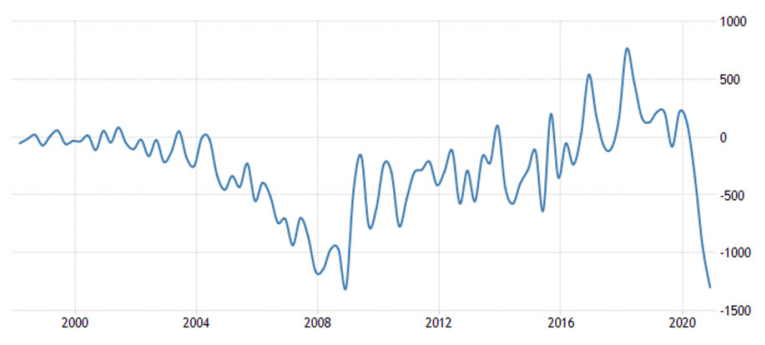

Figure 7. China Capital Flows from 2000 to 2020

In China, international capital flows are calculated using the Capital and Financial Account Balance of the Balance of Payments retrieved from the State Administration of Foreign Exchange [7]. And Figure 7 presents an overview of China's capital flows in the past twenty years. From 2000 to 2006, exports began to take off due to the existing advantages of low-cost labor and China's accession to the World Trade Organization (WTO). However, there was a sharp decline in the capital flows after 2006 and hit the bottom in the 2008 financial crisis. Having endured a gradual economic recovery, in recent years, under the periodic wave motion of the financial market, the capital flows in China still showed an upward trend with solid increases in trade surplus. After 2019, as the global pandemic continued to sweep across the world, China also suffered from increased capital outflows and higher borrowing costs [8]. Meanwhile, Chinese authorities and the central bank have unleashed a series of stimulative policies to help the economy bounce back in the foreseeable future. Overall, the general trend of China's capital flows is strongly linked with external monetary conditions and keeps in line with the world average level.

\subsection{Impact of International Capital Flows on Chinese Financial Market}

International capital flows could bring benefits to the Chinese financial market in innumerable ways. Capital inflows, especially foreign direct investments, can potentially expand access to financing channels and reduce the cost of borrowing, and further increase a country's rate of saving and investment. According to the Reserve Bank of Australia, the investment and saving ratios increased nearly $9 \%-12 \%$ from 2000 to 2004 and may continue to rise [9]. To a large extent, it can be credited to the sizable flow of foreign capital since the reform and opening in the country. Furthermore, the capital movement from advanced economies is often accompanied by the input of technology, advanced skills, and managerial experience, which can contribute to the technology boom and bridge the technical gap in China.

However, as the Asian crisis and the American subprime crisis unfolded, a growing view regarded international capital flows more of as a curse than as a blessing [10]. Compared with the long-term capital flow, short-term capital flows seem to be more likely to create abrupt exchange-rate shifts and lead to "bubbles" in stock and housing markets [11]. On top of that, the flood of speculative capital would also hinder the efforts to control 
domestic liquidity conditions [12]. This kind of hot money is risky to the stability of the financial market due to its speculative features and uncertain flow, especially for immature markets and emerging economies.

\section{Conclusion}

The main goal of the current study was to take a financial overview of international capital flows from 2001 to 2020 and to understand the dynamics behind the cyclical pattern of market fluctuations. This study also finds out that international capital flows are driven by various internal and external factors, and extremely sensitive to changes in the macro-environment. By looking at the internal structure of capital flows in advanced and emerging economies, this paper has identified that emerging economies are more likely to be affected by externality, such as exchange rate, financial crisis, and international relations. In closing, this paper describes the overall trend of China's capital flows over the past two decades and illustrates the benefits and risks that international capital flows might have on Chinese financial markets. These findings from this study contribute in several ways to our understanding of international capital flows and provide a basis for future research work.

\section{References}

1. D. Reinhardt, L. Ricci and T. Tressel, "International Capital Flows and Development: Financial Openness Matters", SSRN Electronic Journal, 2013. Available: $10.2139 /$ ssrn. 2280307 .

2. "COVID-19 and global capital flows", OECD, 2021. [Online]. Available:

http://www.oecd.org/coronavirus/policy-

responses/covid-19-and-global-capital-flows-

2dc69002/. [Accessed: 14- Apr- 2021].

3. A. Marshall, Principles of economics. Amherst, NY: Palgrave Macmillan, 2012, p. Chapter 23. The International Trade and Capital Flows.

4. T. Herold, "What is Capital Outflow? - Herold Financial Dictionary", Herold Financial Dictionary, 2021. [Online]. Available: https://www.financialdictionary.info/terms/capital-outflow/. [Accessed: 14- Apr- 2021].

5. D. Li, "An Economic Analysis of International Capital Flow", American Journal of Industrial and Business Management, vol. 08, no. 02, pp. 404-416, 2018. Available: 10.4236/ajibm.2018.82026.

6. "International Capital Flows: Benefits and Damages | Economics", Economics Discussion, 2021. [Online]. Available:

https://www.economicsdiscussion.net/internationalcapital-movements/international-capital-flowsbenefits-and-damages-economics/30580. [Accessed: 14- Apr- 2021].

7. "China Capital Flows | 1998-2020 Data | 2021-2023 Forecast | Historical | Chart | News",
Tradingeconomics.com, 2021. [Online]. Available: https://tradingeconomics.com/china/capital-flows. [Accessed: 14- Apr- 2021].

8. T. Cai, V. Dang and J. Lai, "China's Capital and 'Hot' Money Flows: An Empirical Investigation", SSRN Electronic Journal, 2015. Available: 10.2139/ssrn. 2633400.

9. D. Orsmond, "Recent Trends in World Saving and Investment Patters | Bulletin - October 2005", Reserve Bank of Australia, 2005. [Online]. Available:

https://rba.gov.au/publications/bulletin/2005/oct/4.ht ml. [Accessed: 14- Apr- 2021].

10. D. Igan, 2016. [Online]. Available: https://blogs.imf.org/2016/12/06/going-with-theflow-benefits-of-capital-inflows-for-emergingmarkets/. [Accessed: 14- Apr- 2021].

11. Y. Ning and L. Zhang, "Modeling dynamics of shortterm international capital flows in China: A Markov regime switching approach", The North American Journal of Economics and Finance, vol. 44, pp. 193203, 2018. Available: 10.1016/j.najef.2018.01.002.

12. F. Broner and R. Rigobon, "Why are Capital Flows so much more Volatile in Emerging than in Developed Countries?", SSRN Electronic Journal, 2004. Available: 10.2139/ssrn.884381.

13. M. Fall, "Trade Flows Versus Capital Flows: Are China's Trade Surpluses

Overestimated?", International Economic Journal, vol. 31, no. 3, pp. 448-461, 2017. Available: 10.1080/10168737.2017.1354905. 